\title{
Perancangan Pembuatan Pengasut Pada Motor Kapasitor 1 Phase
}

\author{
Eka Nur Fahmianto \\ ${ }^{1}$ Universitas PGRI Madiun \\ e.n.fahmianto@gmail.com
}

\begin{abstract}
Perkembangan teknologi di masa sekarang sangat pesat pertumbuhannya itu terlihat dari semakin banyaknya industri-industri yang berdiri dan memproduksi alat-alat teknologi masa kini. Motor-motor induksi sangat penting penggunaanya paling banyak dalam industri dengan skala besar maupun kecil dan di dalam rumah tangga alasannya adalah bahwa karakteristiknya hampir sesusaidengan kebutuhan dunia industri, padaumumnya dalam kaitannya dengan harga,kesempurnaan, pemeliharaan, dan kestabilan kecepatan Motor induksi (asinkron) ini pada umumnya hanya memiliki satu suplai tenaga yang mengeksitasi belitan stator, belitan rotornya tidak terhubung langsung dengan sumber tenaga listrik, melainkan belitan ini dieksitasi oleh induksi dari perubahan medan magnetik yang disebabkan oleh arus pada belitan stator. Hampir semua motor AC yang digunakan adalah motor induksi, seperti motor kapasitor 1 phase. Motor kapasitor merupakan jenis motor yang paling banyak digunakan baik dalam industri maupun dalam rumah tangga. Namun motor ini tidak selalu bekerja pada beban penuh, misalkan di industri yang bebannya selalu berubah. Hal ini akan memperburuk kinerja dari motor kapasitor itu sendiri, salah satunya adalah turunnya faktor daya dan efisiensi motor kapasitor tersebut. Namun disamping dari kekurangan motor kapasitor tersebut, masih bisa diambil manfaatnya yaitu bisa mengatur kecepatan putaran motor kapasitor dengan mengatur besarnya tegangan masukannya yang sesuai dengan besarnya beban yang nantinya juga akan berpengaruh terhadap besarnya faktor daya dari motor induksi itu sendiri. Dengan latar belakang tersebut dan diiringi oleh kemajuan dibidang elektronika daya maka motor induksi dapat diatur besar tegangan masukannya dengan pengaturan sudut penyalaan triac yang diatur dengan potensiometer atau variabel resistor, sehingga motor bisa mendapat tegangan sesuai dengan kebutuhan beban dan putaran pada rotor dapat diatur sesuai kebutuhan.
\end{abstract}

Kata Kunci:

\section{Pendahuluan}

Perkembangan teknologi di masa sekarang sangat pesat pertumbuhannya itu terlihat dari semakin banyaknya industri-industri yang berdiri dan memproduksi alat-alat teknologi masa kini. Motor-motor induksi sangat penting penggunaanya sebagai alat bantu penggerak peralatan lain seperti pada industri perakitan alat-alat transportasi, perakitan alat berat maupun pada industri pertambangan motor induksi sangat dibutuhkan, paling banyak digunakan dalam industri dengan skala besar maupun kecil dan di dalam rumah tangga alasannya adalah bahwa karakteristiknya hampir sesusai dengan kebutuhan dunia 
industri, pada umumnya dalam kaitannya dengan harga, kesempurnaan, pemeliharaan, dan kestabilan kecepatan Motor induksi (asinkron) ini pada umumnya hanya memiliki satu suplai tenaga yang mengeksitasi belitan stator, belitan rotornya tidak terhubung langsung dengan sumber tenaga listrik, melainkan belitan ini dieksitasi oleh induksi dari perubahan medan magnetik yang disebabkan oleh arus pada belitan stator. Hampir semua motor AC yang digunakan adalah motor induksi, seperti motor kapasitor 1 phase.

Motor kapasitor merupakan jenis motor yang paling banyak digunakan baik dalam industri maupun dalam rumah tangga. Namun motor ini tidak selalu bekerja pada beban penuh, misalkan di industri yang bebannya selalu berubah. Hal ini akan memperburuk kinerja dari motor kapasitor itu sendiri, salah satunya adalah turunnya faktor daya dan efisiensi motor kapasitor tersebut. Namun disamping dari kekurangan motor kapasitor tersebut, masih bias diambil manfaatnya yaitu bisa mengatur kecepatan putaran motor kapasitor dengan mengatur besarnya tegangan masukannya yang sesuai dengan besarnya beban yang nantinya juga akan berpengaruh terhadap besarnya faktor daya dari motor induksi itu sendiri. Dengan latar belakang tersebut dan diiringi oleh kemajuan dibidang elektronika daya maka motor induksi dapat diatur besar tegangan masukannya dengan pengaturan sudut penyalaan triac yang diatur dengan potensiometer atau variabel resistor, sehingga motor bias mendapat tegangan sesuai dengan kebutuhan beban dan putaran pada rotor dapat diatur sesuai kebutuhan

\section{Metode Penelitian}

Pada motor kapasitor, pergeseran fase antara arus kumparan utama (Iu) dan arus kumparan bantu (Ib) didapatkan dengan memasang sebuah kapasitor yang dipasang seri terhadap kumparan Kapasitor yang digunakan pada umumnya adalah kapasior elektrolik yang pemasangannya tidak permanen pada motor (sebagai bagian yang dapat dipisahkan). Kapasitor start direncanakan khususnya untuk waktu pemakaian yang singkat, sekitar 3 detik, dan tiap jam hanya 20 kali pemakaian. Bila saat start dan setelah putaran motor mencapai $75 \%$ dari kecepatan penuh, saklar sentrifugal (CS) otomatis akan terbuka untuk memutuskan kapasitor dari rangkaian, sehingga yang tinggal selanjutnya hanya kumparan utama saja. Pada sebagian motor ini ada yang menggunaan relay sebagai saklar sentifugalnya. Ada 2 bentuk pemasangan relay yang biasa digunakan yaitu penggunaan relay arus dan relay tegangan Arus start yang dihasilkan pada gambar 2 cukup besar sehingga medan magnet yang dihasilkan oleh relay sanggup untuk menarik kontak NO (normally open) menjadi menutup (berhubungan), setelah motor berjalan dan mencapai kecepatan $75 \%$ kecepatan nominalnya, maka arus motor sudah turun menjadi kecil kontak NO yang terhubung tadi terlepas 7 kembali karena medan magnet yang dihasilkan tidak sanggup untuk menarik kontak NO sehingga kapasitor dilepaskan lagi dari rangkaian.

Tegangan awal saat start yang dihasilkan pada relay masih kecil sehingga medan magnet yang dihasilkan oleh relay tidak sanggup untuk menarik kontak NC (normally close) menjadi terbuka (memisah), setelah motor berjalan dan mencapai kecepatan $75 \%$ kecepatan nominalnya, maka tegangan pada relay sudah naik menjadi normal sehingga kontak NC yang terlepas tadi terhubung karena medan magnet yang dihasilkan relay sanggup untuk menarik kontak NC menjadi terbuka sehingga kapasitor dilepaskan lagi dari rangkaian.

Triac dapat bersifat konduktif dalam dua arah dan biasa digunakan untuk pengendali fasa ac. Hal ini dapat dianggap sebagai dua buah SCR yang tersambung antipararel. Kerena TRIAC merupakan komponen bidirectional, terminalnya tidak dapat ditentukan sebagai anoda/katode. Jika terminal MT2 positif terhadap MT1. TRIAC dapat dimatikan dengan memberikan sinyal gerbang positif antara gerbang G dan MT1. Jika terminal MT2 negatif terhadap MT1, maka TRIAC dapat dihidupkan dengan memberikan sinyal pulsa negatif antara gerbang dan terminal MT1. Tidak perlu untuk memiliki kedua sinyal gerbang positif dan negatif dan TRIAC dapat dihidupkan baik oleh sinyal gerbang positif maupun negatif. Dalam prakteknya sensitivitas berfariasi antara satu kuadran dengan kuadran lain, dan TRIAC biasanya beroperasi dikuadran I atau kuadran III. (Djatmiko, I.W: 2010)

Dioda merupakan semikonduktor (komponen) elektronika daya yang memiliki dua terminal, yaitu 
anoda dan katoda. Dalam rangkaian elektronika daya, dioda difungsikan sebagai sakelar. Gambar 2.13 (a),(b), dan (c) masing-masing ditunjukkan simbol dioda, karakteristik dioda, karakteristik ideal diode jika dioperasikan sebagai sakelar. Sebagaimana gambar 2.13 (c) dioda akan konduksi (ON) jika potensial pada anoda lebih positif dari pada potensial katoda, dan dioda akan memblok (OFF) jika potensial anoda lebih negatif dari pada potensial katoda. Jika dioda dalam kondisi ideal, ketika diode dalam kondisi ON memiliki karakteristik tegangan pada dioda sama dengan 0 (nol) dan arus yang mengalir pada dioda dalam kondisi OFF memiliki karakteristik tegangan pada dioda sama dengan tegangan sumbernya dan arus yang mengalir sama dengan 0 (nol). Dalam kondisi dioda ON dan OFF ini dapat dinyatakan tidak terjadi kerugian daya pada dioda. (Djatmiko, I.W: 2010)

Diac merupakan komponen elektronika yang terdiri dari dioda empat lapis merupakan peranti dua arah, karena diac dapat mengunci arus dalam dua arah. Rangkaian ekuivalen suatu diac adalah dua buah dioda empat lapis yang dipasang paralel, seperti yang ditunjukkan pada gambar 2.14a, yang secara ideal sama dengan grendel pada gambar 2.14b. Diac tidak akan menghantar sampai tegangan yang melaluinya melebihi tegangan breakover dalam salah satu arah. Sebagai contoh, apabila v memiliki polaritas seperti yang ditunjukkan pada gambar 2.14a, dioda yang berada disebelah kiri akan menghantar saat v melebihi tegangan breakover. Dalam hal ini, grendel yang disebelah kiri tertutup, terlihat pada gambar 2.14c. Saat v memiliki polaritas yang sebalikinya, grendel yang di sebelah kanan akan tertutup. (Malvino, AP:1999, terjemahan Joko Santoso: 2003).

Salah satu komponen elektronika yang berfungsi sebagai penahan arus yang mengalir dalam suatu rangkaian dan berupa terminal dua komponen elektronik yang menghasilkan tegangan pada terminal yang sebanding dengan pada terminal yang sebanding dengan arus listrik yang melewatinya sesuai dengan hukum Ohm. Sebuah resistor tidak memiliki kutub positif dan negatif, tapi memiliki karakteristik utama yaitu resistensi, toleransi, tegangan kerja maksimal dan power ranting. Karakteristik lainya meliputi koefisien temperatur, kebisingan, dan induktansi.

\section{Metode}

Metode yang digunakan pada penelitian ini adalah metode deskriptif kualitatif. Alat dibuat dengan terlebih dahulu dimana kemudian hasilnya dibandingkan dengan teori yang telah ada. Setelah itu baru dilakukan uji coba untuk mengetahui tingkat efisiensi alat tersebut.

Uji coba alat di laboratorium dilakukan pada motor sebelum dipasang alat pengasut dan setelah dipasang alat pengasut. Kedua hasil tersebut kemudian dibandingkan Data yang diperoleh nantinya berupa seberapa besar kecepatan putaran dari motor listrik sebelum dan sesudah diberi pengasut.

\section{Pembahasan}

Pengujian dilakukan dengan mengukur tegangan, arus dan kecepatan putaran motor kapasitor sebelum alat dipasang, yang detilnya dapat dilihat pada tabel 1 . Hasil tersebut diperoleh dari hasil uji coba di laboratorium.

Tabel 1 Tegangan, arus dan kecepatan putaran motor sebelum alat dipasang

\begin{tabular}{|c|l|c|c|c|}
\hline No & \multicolumn{1}{|c|}{ Jenis motor } & Tegangan & Arus & $\begin{array}{c}\text { Kecepatan Putaran } \\
(\mathrm{Rpm})\end{array}$ \\
\hline 1 & Za-yl802-4b3 & 220 volt & $4,6 \mathrm{~A}$ & $1400 \mathrm{rpm}$ \\
\hline 2 & Domax YL 7112 & 220 volt & $2,73 \mathrm{~A}$ & $2800 \mathrm{rpm}$ \\
\hline 3 & Domosa DB-125 & 220 volt & $1,6 \mathrm{~A}$ & $2850 \mathrm{rpm}$ \\
\hline
\end{tabular}

Selanjutnya tegangan, arus, dan kecepatan putaran pada motor setelah diopersikan, diukur dengan hasil pengukuran yang ditunjukkan pada tabel 2, 3 dan 4 
Tabel 2 Tegangan, Arus, dan kecepatan putaran pada motor 1

\begin{tabular}{|l|c|c|c|c|}
\hline No. & $\begin{array}{c}\text { Posisi } \\
\text { Rotary swit }\end{array}$ & $\begin{array}{c}\text { Tegangan } \\
(\text { volt })\end{array}$ & Arus (A) & $\begin{array}{c}\text { Kecepatan putaran motor } \\
(\mathrm{rpm})\end{array}$ \\
\hline 1. & 1 & 220 volt & $4,00 \mathrm{~A}$ & $1240,0 \mathrm{rpm}$ \\
\hline 2. & 2 & 220 volt & $3,43 \mathrm{~A}$ & $909,1 \mathrm{rpm}$ \\
\hline 3. & 3 & 220 volt & $3,01 \mathrm{~A}$ & $738,3 \mathrm{rpm}$ \\
\hline 4. & 4 & 220 volt & $2,73 \mathrm{~A}$ & $354,9 \mathrm{rpm}$ \\
\hline 5. & 5 & 220 volt & $2,40 \mathrm{~A}$ & $199,7 \mathrm{rpm}$ \\
\hline 6. & 6 & 220 volt & $2,02 \mathrm{~A}$ & $89,90 \mathrm{rpm}$ \\
\hline
\end{tabular}

Tabel 3 Tegangan, Arus, dan kecepatan putaran pada motor 2

\begin{tabular}{|l|c|c|c|c|}
\hline No. & $\begin{array}{c}\text { Posisi } \\
\text { Rotary swit }\end{array}$ & $\begin{array}{c}\text { Tegangan } \\
(\text { volt })\end{array}$ & Arus (A) & $\begin{array}{c}\text { Kecepatan putaran motor } \\
(\mathrm{rpm})\end{array}$ \\
\hline 1. & 1 & 220 volt & $2,62 \mathrm{~A}$ & $2764 \mathrm{rpm}$ \\
\hline 2. & 2 & 220 volt & $2,47 \mathrm{~A}$ & $2381 \mathrm{rpm}$ \\
\hline 3. & 3 & 220 volt & $2,22 \mathrm{~A}$ & $2070 \mathrm{rpm}$ \\
\hline 4. & 4 & 220 volt & $2,03 \mathrm{~A}$ & $1759 \mathrm{rpm}$ \\
\hline 5. & 5 & 220 volt & $1,81 \mathrm{~A}$ & $1431 \mathrm{rpm}$ \\
\hline 6. & 6 & 220 volt & $1,64 \mathrm{~A}$ & $1053 \mathrm{rpm}$ \\
\hline
\end{tabular}

Tabel 4 Tegangan, Arus, dan kecepatan putaran pada motor 3

\begin{tabular}{|l|c|c|c|c|}
\hline No. & $\begin{array}{c}\text { Posisi } \\
\text { Rotary swit }\end{array}$ & $\begin{array}{c}\text { Tegangan } \\
(\text { volt })\end{array}$ & Arus (A) & $\begin{array}{c}\text { Kecepatan putaran motor } \\
(\mathrm{rpm})\end{array}$ \\
\hline 1. & 1 & 220 volt & $1,52 \mathrm{~A}$ & $2817 \mathrm{rpm}$ \\
\hline 2. & 2 & 220 volt & $1,37 \mathrm{~A}$ & $2027 \mathrm{rpm}$ \\
\hline 3. & 3 & 220 volt & $1,29 \mathrm{~A}$ & $1893 \mathrm{rpm}$ \\
\hline 4. & 4 & 220 volt & $1,02 \mathrm{~A}$ & $1671 \mathrm{rpm}$ \\
\hline 5. & 5 & 220 volt & $0,84 \mathrm{~A}$ & $1254 \mathrm{rpm}$ \\
\hline 6. & 6 & 220 volt & $0,73 \mathrm{~A}$ & $784 \mathrm{rpm}$ \\
\hline
\end{tabular}

Berdasarkan hasil pengujian dari rangkaian pengendali, maka didapatkan bahwa pengsut motor kapasitor 1 phase dapat mengubah kecepatan putaran pada motor. Setiap posisi rotary swit 1-6 nilai kecepatan putaran pada motor berbeda, apabila semakin naik posisi rotary swit maka nilai kecepatan putaran motor semakin kecil/menurun. Pada hasil pengujian ini arus yang masuk pada motor juga ikut menurun jika posisi rotary swit semakin naik. Sehingga energi/daya yang dibutuhkan pada motor semakin kecil, maka dapat menghemat energi/daya.

Tabel 5 Perbedaan daya antara memakia alat dan tidak memakai

\begin{tabular}{|l|l|}
\hline $\begin{array}{c}\text { Daya normal tanpa pengasut pada } \\
\text { motor 1 }\end{array}$ & $\begin{array}{c}\text { Daya yang sudah dipasang } \\
\text { pengasut posisi rotary swit 3 pada } \\
\text { motor 1 }\end{array}$ \\
\hline $\begin{aligned} \mathrm{P}=\mathrm{V} \times \mathrm{I} \\
=220 \mathrm{x} 4,6 \\
=1012 \text { watt }\end{aligned}$ & $\begin{array}{r}\mathrm{P}=\mathrm{V} \times \mathrm{I} \\
=220 \times 3,01 \\
=662,2 \text { watt }\end{array}$ \\
\hline
\end{tabular}

Berdasarkan hasil pengujian dari keseluruhan komponen, maka didapatkan bahwa pengasut motor kapasitor 1 phase dapat bekerja sesuai dengan perancangan. Setiap bagian blok dari rangkaian dapat bekerja dengan baik. Output dari alat ini adalah dapat mengatur kecepatan putaran pada motor dan mampu menghemat enegri/daya yang dibutuhkan dengan pengaturan kecepatan putaran pada motor.

\section{Kesimpulan}

Berdasarkan hasil penelitian yang telah dilakukan maka dapat disimpulkan sebagai berikut: 1. Dari hasil pengujian diketahui bahwa pengasut motor kapasitor 1 phase dapat bekerja sesuai dengan 
perencanaan. 2. Pengasut motor kapsitor 1 phase dapat difungsikan sebagai penghemat energi/daya serta dapat digunakan sebagai pengatur kecepatan putaran pada motor kapasitor 1 phase.

\section{Daftar Pustaka}

[1] Aksin, M. 2001. Merancang Sendiri PCB. Semarang: Effhar Offset

[2] Daryanto. 2000. Pengetahuan Teknik Elektro. Jakarta: Bumi Aksara

[3] Djatmiko, I.W. 2010. Elektronika Daya. Yogyakarta: Universitas Negeri Yogyakarta

[4] Hasanah, R.N. 2012. Kajian terhadap Upaya Penghematan Energi pada Aplikasi Motor Kapasitor, 1 (6):61-66.

[5] Malvino, A.P. 1999. Prinsip - Prinsip Elektronika, edisi pertama. diterjemahkan oleh Joko Santoso. Jakarta: Salemba Teknika

[6] Petruzella, F.D. 2010. Electric Motors and Control Systems. New York: Mc Graw-Hill

[7] Rahman, A. 2006. Keterampilan Elektronika. Jakarta: Ganeca Exact

[8] Sumanto. 1993. Motor Listrik Arus Bolak Balik. Yogyakarta: Andi Offset 